\begin{tabular}{l|l} 
Votaice & e-ISSN: 2655-9404 p-ISSN: 2721-8376 \\
Vol. 3 No. 1, Februari 2020 & DOI: 10.20473/ntr.v3i1.18554 \\
\hline
\end{tabular}

Article history: Submitted 5 January 2020 ; Accepted 15 January 2020; Available online 1 February 2020.

\title{
The Agrarian Law Policy in the Control of Residence by Expatriates in Indonesia
}

\author{
Corina Ealen Meilan Danu, Ketut Briliawati Permanasari, \\ Wilujeng Jauharnani, Ria Yunita Sari \\ wiwiek.nani@yahoo.co.id \\ Universitas Airlangga
}

\begin{abstract}
The state has the right to control the land, waters and natural resources contained therein to achieve the greatest benefit of the people. According to the provisions of Article 9 paragraph (1) and Article 26 paragraph (2) of the Law of the Republic of Indonesia Number 5 of 1960 concerning Basic Regulations on Agrarian Principles, property rights may only be owned by Indonesian citizens. Based on these conditions, expatriates cannot have a residence in Indonesia. On the other hand, Indonesia as a subject of international law has the responsibility in protecting the right of expatriates to dominate residence in Indonesia. In this study, the state responsibility for the provision of residence for foreigners and the regulations that provide space for expatriates in the mastery of residence in Indonesia will be discussed. In international law, there are principles of state responsibility. This principle mandates that the state guarantees protection of foreigners, including the place of residence for foreigners. The development of regulations in Indonesia provides a solution to the control of residence by expatriates. The legal solution offered is the control of residence with a tenancy agreement between expatriates and homeowners who are Indonesian citizens or by using the right of use. The right of use a residence given to the expatriates is in the form of a single house and apartment units that are limited by the price and area of land in accordance with the applicable regulations.
\end{abstract}

Keywords: State Responsibility; Agrarian Law Policy; Residence; Expatriates.

\footnotetext{
Abstrak

Negara memiliki hakmenguasai atas tanah, dimana bumi, air dan kekayaanalamyang terkandung di dalamnya oleh negara adalah guna mencapai sebesar-besarnya kemakmuran rakyat. Menurut ketentuan Pasal 9 ayat (1) dan Pasal 26 ayat (2) Undang-Undang Republik Indonesia Nomor 5 Tahun 1960 Tentang Peraturan Dasar Pokok-Pokok Agraria, hak milik hanya boleh dimiliki oleh warga negara Indonesia. Berdasarkan ketentuan tersebut maka ekspatriat tidak dapat memiliki tempat tinggal di Indonesia. Di sisi lain, Indonesia sebagai subjek hukum internasional memiliki tanggung jawab dalam melindungi hak ekspatriat untuk menguasai tempat tinggal di Indonesia. Dalam penelitian ini akan dibahas tanggung jawab negara dalam penyediaan tempat tinggal bagi ekspatriat dan peraturan yang memberikan ruang bagi ekspatriat dalam penguasaan tempat tinggal di Indonesia. Dalam hukum internasional, terdapat prinsip tanggung jawab negara. Prinsip ini mengamanatkan agar negara menjamin perlindungan terhadap WNA, termasuk terhadap tempat tinggal bagi WNA. Perkembangan regulasi di Indonesia memberikan solusi atas penguasaan tempat tinggal oleh ekspatriat. Solusi hukum yang ditawarkan adalah penguasaan tempat tinggal dengan perjanjian sewa-menyewa antara ekspatriat dengan pemilik rumah yang berkewarganegaraan Indonesia atau dengan hak pakai. Hak pakai tempat tinggal yang diberikan kepada ekspatriat berupa rumah tunggal dan satuan rumah susun yang dibatasi dengan harga dan luas lahan sesuai dengan peraturan yang berlaku.

Kata Kunci: Kebijakan Hukum Agraria; Tempat Tinggal; Ekspatriat.
} 


\section{Introduction}

The government has a responsibility to improve people's welfare. The central government is concerned about the increasing geographical gap in gains from national economic growth, and is aiming to accelerate development in these areas. ${ }^{1}$ In an effort to overcome this gap, the government controls the land control. Since the Basic Agrarian Law came into force, there has been a fundamental shift in land law, toward Indonesian agrarian law, placing these issues directly under governmental control. ${ }^{2}$ Article 2 paragraph (1) the Law of the Republic of Indonesia Number 5 of 1960 concerning Basic Regulations on Agrarian Principles states that based on the provisions in article 33 paragraph (3) of the Constitution and matters as referred to in article 1, earth, water and space, including the natural resources contained therein are at the highest level controlled by the State, as an organization of power for all people. This provision leads to the State's rights of control in which the earth, waters and natural riches at the highest level are controlled by the state, as an organization of power for all citizens.

The State's rights of control the land is further regulated in Article 2 paragraph (2) of the Law of the Republic of Indonesia Number 5 of 1960 concerning Basic Regulations on Agrarian Principles. The rights of controlled by the State meant in paragraph (1) of this Article provides authority:

a. To regulate and implement the appropriation, the utilization, the reservation and the cultivation of that earth, water and air space;

b. To determine and regulate the legal relations between persons concerning the earth, water and air space;

c. To determine and regulate the legal relations between persons and legal acts concerning the earth, water and air space.

The regulation of land rights is important because it authorizes the holder, whether it is the authority to use the land, including the layers of earth, water and

\footnotetext{
1 L' Kristiansen, S. \& Sulistiawati, 'Traditions, Land Rights, and Local Welfare Creation: Studies from Eastern Indonesia' (2016) 52 Bulletin of Indonesian Economic Studies.[210].

2 JA Hartanto, 'Legal Aspects of Land Purchase/Sale Disputes in Indonesia' (2018) 48
} Environmental Policy and Law.[79]. 
space above it, as well as the special powers to use the land according to the type of land rights. ${ }^{3}$ In connection with the State's rights of control the land, the State has the authority to arrange regulations in the control of residence by expatriates in Indonesia. Expatriation (from the Latin ex-patria: out of country) has existed from the time that there were countries for people to expatriate from. ${ }^{4}$ Expatriates are basically foreign nationals living permanently in Indonesia. The existence of expatriates in a country is considered important as the technology experts and in the transfer of knowledge. Their knowledge can fill the knowledge gap of the individual or team who becomes their companion through knowledge acquisition, and supported by the expertise and knowledge owned by the local staff before, it is expected that the local staff can improve their capabilities and capacities, so that accumulation can build individual or team competencies. ${ }^{5}$ The recruitment of expatriates is expected to bring foreign and more developed knowledge and skills to the corporate asset. ${ }^{6}$

In the provisions of Article 9 paragraph (1) of the Law of the Republic of Indonesia Number 5 of 1960 concerning Basic Agrarian Principles determines "Only Indonesian citizens may have the fullest relation with the earth, water, and air space within the limits mentioned in Article 1 and 2." This provision explicitly prohibits the land ownership by the expatriates, although it is used for residence. The prohibition on land ownership by foreign citizens is also emphasized in Article 26 paragraph (2) of the Law of the Republic of Indonesia Number 5 of 1960 concerning Basic Regulations on Agrarian Principles stating each sale and purchase, exchange, gift, bequest by will and other acts which are meant to transfer the right of ownership directly or indirectly to a foreign, to a national

3 A Sudiro, 'Measuring the Openness of Land Investment Policy Related to Housing or Residential Ownership by Foreigners in Indonesia' (2018) 21 European Research Studies Journal. [166].

4 C McNulty, Y., \& Brewster, "Theorizing the Meaning (s) of "Expatriate": Establishing Boundary Conditions for Business Expatriates' (2017) 28 The International Journal of Human Resource Management.[29].

5 D Prihadyanti, D., Sari, K., \& Hidayat, 'Peran Ekspatriat Dalam Penguatan Kompetensi Inti Perusahaan' (2018) 17 Journal of Technology Management.[146].

6 Pangestu, S., \& Dharmastuti, C. F., 'What Characteristics of Board of Directors Affect Indonesian Bank Performance' (2018) 6 International Journal of Accounting and Economics Studies.[49]. 
possessing a foreign nationality in addition to his/her Indonesian nationality, or to a corporation, except those which have been by the Government as meant in Article 21, clause (2) are not valid by law the provision the rights of another party incumbent therein remain valid and that all payments which have been received by the owner may not be reclaimed.

Provisions on limiting the sale of land to foreigners and foreign corporation have been existing for a long time in several countries. Such restrictions are often associated with "closed societies" or developing countries, for example, Singapore which has limited land sales to foreigners, but allows the sale of land for residence to foreign corporation for their expatriates. China also has restricted the sale of land to foreigners for a long time, but the land rent is possible for foreigners. Middle Eastern countries, referred to as "closed societies" because of the Moslem dominance, do not allow the sale of land to foreigners and foreign corporation for any purpose. ${ }^{7}$

Legal provisions in Indonesia prohibit the sale of land to foreign nationals. As a result, the expatriates use nominee agreements to control of land in Indonesia. The embodiment of this nominee is in the agreement made by the parties, namely between foreign and Indonesian citizens as nominees made through a package of agreements which essentially intends to give all authority that may arise in a legal relationship between a person with the land to foreign nationals as the endorsee to act as an actual owner of a piece of land according to law in Indonesia it cannot be owned, namely the right of ownership.

The nominee agreement is a legal smuggling carried out in cooperation with Indonesian citizens, foreign nationals, notaries and Land Deed Makers Officer (Pejabat Pembuat Akta Tanah). This legal act is very risky and can harm expatriates who want to have a residence in Indonesia. In dealing with these legal problems, there are several regulations that have been provided by the government so that expatriates can control the land to be used as a residence. In this study, it will

\footnotetext{
7 L Sumanto, 'Pembatasan Pemilikan Hak Atas Tanah Oleh Orang Asing Dan Badan Hukum Asing (Studi Perbandingan Indonesia-Turki)' (2016) 3 Jurnal Hukum PRIORIS.[68].
} 
be discussed the state responsibility for the provision of residence for foreigners and the regulations that provide space for expatriates in the mastery of residence in Indonesia. Legal solutions to the problems of the control of residence by expatriates are very important considering their contributions to the development of technology, science, economic and investment in Indonesia.

\section{Method Research}

This research is a normative legal research which examines the state responsibility for the provision of residence for foreigners and the regulations that provide space for expatriates in the mastery of residence in Indonesia will be discussed. The approach used in this research is the legal approach and legal concept approach. The approach is used to examine existing laws and and by examining the legal principles that form the basis of consideration in the protection of foreign nationals to reside in Indonesia. Legal material consists of primary and secondary legal materials collected through library research. The analysis was carried out qualitatively. A qualitative approach is carried out by analyzing legal actions carried out by expatriates and framing them in the provisions of existing legislation to recommend better regulations in the future.

\section{The state responsibility for the provision of residence for foreigners}

\section{State control of land and its arrangements}

The State has the rights to control the land. General Explanation I of the Law of the Republic of Indonesia Number 5 of 1960 concerning Basic Regulations on Agrarian Principles states that there are 3 (three) main objectives of the agrarian law namely:

1. laying the foundations for the formulation of national agrarian law which will be a tool to bring prosperity, happiness and justice to the State and the people, especially the peasantry, in the context of a just and prosperous society;

2. laying the foundations for the unity and simplicity in land law;

3. laying the foundations for providing legal certainty regarding land rights for 
the whole people.

Land rights are rights that authorize the right holders to use and take advantage of the land they own. In terms of the origin of the land, land rights are divided into two groups, namely:

1. Primary land rights, namely land rights originating from State land. The kinds of rights to this land are Right of Ownership, Right of Exploitation, Right of Building on State Land, Right of Use on State Land.

2. Secondary land rights, namely land rights originating from the land of another party. The types of rights to this land are the Right of Building on Land Over the Management Right, Right of Building for Land of the Right of Ownership, Right of Use on Land of Management Right, Right of Use Ownership Land, Right to Lease Land for Buildings, Pawn Rights (Land Pawn), Profit Sharing Rights (Production Sharing Agreement) Renting Rights, and Right to Rent Land from Agriculture. ${ }^{8}$

In the Law of the Republic of Indonesia Number 5 Year 1960 concerning Basic Regulations on Agrarian Principles, several primary land rights are regulated, namely:

a. The right of ownership. Provisions regarding the right of ownership are regulated in Article 20-27 of the Law of the Republic of Indonesia Number 5 of 1960 concerning Basic Regulations on Agrarian Principles. The right of ownership is hereditary right and be strongest and fullest right one can have on land. This right may go over to and be transferred to other party. Sales, and purchases, exchanges, gift, bequest by will, bequest according to customary law and other act which are meant to transfer the right of ownership and its control shall be regulated by Government Regulation. Each sale and purchase, exchange, gift, bequest by will and other acts which are meant to transfer the right of ownership directly or indirectly to foreign, to a national possessing a foreign nationality in addition to his/her Indonesian nationality, or to a 
corporation, except those which have been by the Government as meant in Article 21 paragraph (2), are not valid by law the provision that rights of another party incumbent therein remain valid and all payments received by the owner may not be reclaimed. The right of ownership is annulled deleted if a. the land fall back to the State (due to the revocation of right based on Article 18 ; voluntary transfer by its owner; the land is lying fallow, the provisions in Article 21, clause (3) and Article 26 clausa (2)); and b. the land is destroyed.

b. The right of exploitation. Provisions regarding the right of exploitation are regulated in Article 28-Article 34 of the Law of the Republic of Indonesia Number 5 of 1960 concerning Basic Regulation on Agrarian Principles. The right of exploitation is the right to cultivate the land which is directly controlled by the State for a period of time as stipulated in Article 29 for enterprises in the field of agriculture, fishery or cattle breeding. This right is granted on land which size at least 5 hectares with the provision that, if its size is 25 hectares or more, a reasonable investment of capital shall have to be used coupled with a good management technique in line with the development of time. The right of exploitation may go over and be transferred to another party. This right is granted for a period of not longer than 25 years. To an enterprise that needs a longer period, this right for not longer than 35 years may be granted. At the request of the holder of the right and considering the situation of his enterprise the period of time may be extended with a period of not longer than 25 years. Those who may have the right of exploitation are Indonesian citizens and corporations which has been established according to the Indonesian law and have their seat in Indonesia. Persons or corporation possessing this right and who do not any longer meet the terms as mentioned above are obliged within a period of 1 year to relinquish or to transfer that right to another party meeting these terms. This provision is also applicable to a party which has obtained the right of exploitation if his party does not meet the meant terms. If the right of exploitation concerned is not relinquished or transfered within the mentioned period of time, then that right become not 
34 Corina Ealen, dkk: The Agrarian Law Policy...

valid by the law, with the provision that the rights of the other party shall be observed according to the provision laid down by Government Regulation. The right of exploitation, including the requirements of its issues, as well as each transfer and annulment of this right must be registered. The registration constitutes a means of string evidence concerning the transfer as well as the annulment of the right of exploitation except in the case that the aforementioned right is annulled due to the expiration of its period. The right of exploitation mau be made a security for a debt by meant of right of security. The right of exploitation is annulled because of: expire of its period; its termination before its expiration due to non fulfillment of a requirement; the abandonment by the holder of the right holder before its date of expire; its annulment in the public interest; its being neglected; the destruction of the land; the provisions of Article 30 paragraph (2) of the Law of the Republic of Indonesia Number 5 of 1960 concerning Basic Regulations on Agrarian Principles.

c. The right of building. Provisions concerning the right of building is regulated in Article 35-Article 40 of the Law of the Republic of Indonesia Number 5 Year 1960 concerning Basic Regulation on Agrarian Principles. The right of building is the right to build and own buildings on land which is not one's property for not longer than 30 years. At the request of the holder of the right and considering the necessity as well as the condition of the building, the period of time meant can be extended by a period not longer than 20 years. This right may go over to and be transferred to another party.Those who may possess the right of building are: Indonesian citizen and corporation established according toIndonesian law and having their domicile in Indonesia. Person or corporation who possess the right of building and do not linger meet the requirement mentioned are obliged within a period of one year to relinquish or to transfer that right to another party that meets the requirements. This provision also applies to the party that obtains the right of building, if does not meet the said requirements. If the right of building concerned is not relinquished or transferred in the period as mentioned above the right becomes not valid 
by law with the provision that right of the other parties shall be transferred, according to the provisions to be laid down by Government Regulations.

The right of building is originated with regard to land which is directly controlled by the State because of the Government verdict and with regard to land under right property; because of an agreement of authored nature between the owner of the land building, aiming at the establishment of the above mentioned right. The right of building including its requirements of granting as well as its transfer and annulment of that right must be registered according to provisions mentioned. The registration constitutes a means of strong evidence concerning the annulment of the right of building as well as the validity of the transfer of above mentioned right, except in the case that those rights are annulment because of expire of the period. The right of building can be used as collateral for debt by being burdened with mortgages. This right is annulled because of: expire of its period; its termination before the expiration of its period due to non-fulfillment of certain requirements; its abandonment by the holder of the right before expire of its period; its annulment in the public interest; of is lying fallow (being neglected); destruction of the land; and the provision in Article 36 paragraph (2) of the Law of the Republic of Indonesia Number 5 of 1960 concerning Basic Regulations on Agrarian Principles.

d. The right of use. Provisions regarding the right of use are regulated in Article 41-Article 43 of the Law of the Republic of Indonesia Number 5 of 1960 concerning Basic Regulations on Agrarian Principles. The right to use is the right to use and / or collect the product, from land directly controlled by the State, or land owned by other persons, which gives the rights and obligations stipulated in the decision upon grating this right by the authorized official, or in an agreement to work the land, as far as it not conflict with the spirit an the provision of this law. The right of use may be granted for a certain period of time or as long as the land is utilized for a specific purpose and for free, against payment, or against services in whatever form. The granting of the right of use may not 
be accompanied by conditions bearing elements of extortion. Those who may obtain the right of use are Indonesian citizens; foreigners residing in Indonesia; corporation which have been established according to Indonesian law and having their seat in Indonesia; and foreign corporations having a representation in Indonesia. As far it concerns land directly controlled by the State, the right of use may only be transferred to another paazrty with the permission of the authorized official. The right of use of land with right of ownership may only be transferred to another party, if this is possible in the agreement concerned.

The consideration of state responsibility for the provision of residence for foreigners

Land governance represents the capacity to address land-use policy choices, enforce relevant regulations, and coordinate with stakeholders and official agencies across different administrative levels of decision- making. ${ }^{9}$ One form of land regulation by the government is the regulation of the ownership of the residence. Residence is a basic need for humans. It has an important meaning in the field of law, which is one of the places where legal actions are taken. The importance meaning (relevance) of residence for a person or corporation is in terms of fulfilling rights and obligations, determining one's legal status in the legal traffic, and relating to court competence. The residence determines whether a person is bound to fulfill his rights and obligations in every legal event. It also determines a person's legal status whether he or she is in a marital bond, whether he or she is not yet an adult, whether he or she is not capable of doing so. It also determines if someone is dealing with the court. ${ }^{10}$

The ownership of residence is a basic right for everyone. According to Titon Human rights are divided into two types, namely individual rights and human

\footnotetext{
9 Huang, Chun-Wei, Robert I. McDonald, and Karen C. Seto, Robert I. McDonald, 'The Importance of Land Governance for Biodiversity Conservation in an Era of Global Urban Expansion' (2018) 173 Landscape and Urban Planning.[44].

10 IS Randang, 'Tinjauan Yuridis Tentang Peranan Identitas Domisili dalam Menentukan Kompetensi Relatif Pengadilan' (2016) 4 Lex Privatum.[25].
} 
rights as social beings. Individual rights are the right of life and life development such as the right of inner freedom, right of good reputation, the right of freedom in religion and so on. These basic rights are arranged primarily for the protection of the persons against state power. Ownership of residence is an individual human right as well as a human right as a social being. Residence can be a domicile of a person or legal entity. The purpose of determining the domicile is to make it easier for the parties to carry out legal relations, namely a legal act that causes legal consequences. ${ }^{11}$ The choice of domicile is regulated in Article 24 of the Civil Code which states as follows:

Parties shall be entitled, or one of the parties shall be entitled, pursuant to a deed, and due to specific circumstances to choose a residence other than their actual one. The choice may be general, and shall extend even to the execution or shall be limited in a manner as approved by the parties or one of them. In such event, the writs, summons and warrants, expressed or implied in the deed, shall be served at the selected place of residence and in the presence of the judge of such location.

In determining the choice of domicile, there are at least four things that need to be considered, namely the choice must occur with an agreement, the agreement is made in written form, the choice can only occur for one or more legal actions or certain legal relationships and the choice is due to reasonable interests. ${ }^{12}$ Legally, all Indonesian citizens have the right to own land in Indonesia without any limitation or differentiation from the Central Government or the Regional Government. The inherent nature of state power in land tenure is reflected in the various formulations of the Law governing the use, use and transfer of land functions. ${ }^{13}$

In relation to the principle of protection of human rights, the state is not only an obligation in guaranteeing the ownership of land by Indonesian citizens, but also has an obligation in regulating the control of land by foreigners to be used as

\footnotetext{
11 Titik Triwulan Tutik, Hukum Perdata Dalam Sistem Hukum Nasional (Kencana Prenada Media Group 2011).[58].

12 ibid.[62].

${ }^{13}$ Natanael Dwi Reki, ‘Pembatasan Pemilikan Dan Penguasaan Hak Atas Tanah Dalam Perspektif Reforma Agraria' (2018) 1 Jurnal Hukum Magnum Opus.[40].
} 
38 Corina Ealen, dkk: The Agrarian Law Policy...

a residence. The obligation of the state in regulating the mastery of residence by foreigners was born from the principle of state responsibility. The principle of the responsibility of the state itself arises from primary rules of obligation.

In Article 9 Montevideo Convention on the Rights and Duties of States stated that "The jurisdiction of states within the limits of national territory applies to all the inhabitants. Nationals and foreigners are under the same protection of the law and the national authorities and the foreigners may not claim rights other or more extensive than those of the nationals." Furthermore, in Article 13 paragraph (1) The Universal Declaration of Human Rights states "Everyone has the right to freedom of movement and residence within the borders of each state." In international law there are two opinions regarding the state's responsibility towards foreigners, which are as follows:

a. International Minimum Standard. This view is shared by developed countries, according to this opinion treating foreigners in the country must meet international minimum standards, which are in accordance with international law and effective protection according to international law. If these requirements are not met, then state liability arises.

b. National Treatment Standard. This standard was discovered by developing countries that were born as a reaction to international minimum standards. According to this standard, foreigners must be treated the same as the state treats its citizens. ${ }^{14}$

As a middle ground of the doctrine of the International Minimum Standards and National Treatment Standards, Garcia Amandor expressed his opinion regarding the responsibility of the state, especially with regard to the treatment of foreigners, namely as follows:

1. Foreigners enjoy the same rights and guarantees as the citizens of their country of residence, no less than guarantees to enjoy fundamental human rights that have been established and recognized by international law. [293].

${ }^{14}$ Huala Adolf, Aspek-Aspek Negara Dalam Hukum Internasional (PT Raja Grafindo Persada 2002). 
2. If these rights are violated, the state will bear responsibility towards the perpetrators. In this case the country of origin can carry out diplomatic protection. For this reason, the country of origin needs to understand the legal principles that apply in the country where citizens live ${ }^{.15}$

Normatively, state responsibility towards citizens can be seen in Article 9 of the Montevideo Convention on the Rights and Duties of States which states "The jurisdiction of states within the limits of national territory applies to all the inhabitants. Nationals and foreigners are under the same protection of the law and the national authorities and the foreigners may not claim rights other or more extensive than those of the nationals."

A country is responsible for foreigners and their property in the territory of their country. Multilateral and regional international treaties or through national law determine the rights and obligations of the state against foreigners who are in the territory of a country, violation of these obligations causes the state to be responsible for these foreigners. In addition, there is also a reason for the emergence of state accountability as a result of actions taken by organs or officials in the form of mistreatment towards foreigners and actions or negligence that are economically and physically detrimental to the state against foreigners. ${ }^{16}$

Indonesia as a subject of international law has the responsibility to provide solutions for the mastery of residence for expatriates. Judging from the existing laws and regulations in Indonesia, there are two models that can be legitimate for expatriates to use a residence in Indonesia, namely through a lease agreement and through the provisions regarding the right to use.

The regulations that provide space for expatriates in the mastery of residence in Indonesia

a. Legal Aspects of Tenancy Agreements of Residence by Expatriates

\footnotetext{
15 ibid.[294-295].

16 Jawahir Tontowi dan Pranoto Iskandar, Hukum Internasional Kontemporer (Refika Aditama 2006). [206].
} 
In the provisions of agrarian law in Indonesia, expatriates cannot have the right of ownership on land; therefore, they cannot buy a residence. Nevertheless, they can rent residences from Indonesian citizens. These legal actions are stated in the leasing agreement. The right to lease land for building is regulated in Article 44 and Article 45 of the Republic of Indonesia Law Number 5 of 1960 concerning Basic Agrarian Principles. In Article 44 is determined (1) A person or a corporation has a right to lease land, if he is entitled to utilize land owned by another for the purpose of building, by paying to its owner an amount of money as rent. (2) The payment of rent may be effected once or at intervals; before or after use of the land. (3) Agreement for the lease of land meant in this Article may not be accompanied by conditions having the element of extortion. The provisions in Article 45 regulate legal subjects who may become holders of the right to lease, namely Indonesian citizens; foreigner residing in Indonesia; corporation which has been established according to Indonesian law and having their seats in Indonesia; and foreign corporation having a representative in Indonesia.

According to Abdulkadir Muhammad, the act of leasing includes five elements, namely approval, submission of a rented object, payment of rent, lease time and leasing requirements, namely:

a. Approval is an act that states that an agreement is reached between the parties, namely the party that rents out with the lessee regarding the rented object, price of rent, time to rent and other leasing requirements.

b. Submission of a rented object is a legal action with the intention of transferring the right of ownership of a leased object from the party that rents to the lessee to enjoy the right of the leased object.

c. Payment of rent is a counter-performance in the form of giving an amount of money from the lessee to the party who rents out the object controlled by the lessee.

d. Rental time is the length or duration of the lease.

e. Leasing requirements are the conditions that have been mutually agreed between the party that rents out with the lessee to enable the acquisition of rights and fulfillment of obligations between the parties. ${ }^{17}$

The tenancy agreement is based on the general principle in the contract law,

${ }_{17}$ Abdulkadir Muhammad, Hukum Perdata Indonesia (Citra Aditya Bakti 2014).[346]. 
namely the principle of freedom of contract. The freedom of contract principle explains that parties are legally free to determine the things they want to describe in the agreement or contract they make. If they have signed a contract, the parties are no longer free, but have been bound to what has been mentioned in the contract. ${ }^{18}$

\section{b. The right of use in the residence ownership for expatriates}

The agrarian law policy in residence permits for expatriates has experienced significant developments. The government policy is outlined in the Republic of Indonesia Government Regulation No. 103 of 2015 concerning Housing Ownership or Occupancy by Foreigners Domiciled in Indonesia, Minister of Agrarian and Spatial Regulation / Head of the National Land Agency of the Republic of Indonesia Number 29 of 2016 concerning Procedures for Granting, Disposal, or Transfer of Right to Residential Ownership by Foreigners Domiciled in Indonesia and Minister of Law and Human Rights Regulation of the Republic of Indonesia Number 23 of 2016 concerning Foreigners and Heirs as Owners of Residential or Residential Houses that Are No Longer Residing in Indonesia.

In the basis of considering the Republic of Indonesia Government Regulation No. 103 of 2015 concerning Housing Ownership or Occupancy by Foreigners Domiciled in Indonesia stated that the provision was made in order to implement the provisions of Article 42 of Law Number 5 of 1960 concerning Basic Regulations on Agrarian Principles, and to further provide legal certainty of ownership of residential houses or dwelling by foreigners domiciled in Indonesia, the Government Regulation Number 41 of 1996 concerning Housing Ownership or Residential by Foreigners domiciled in Indonesia needs to be replaced.

In the General Explanation of the Government Regulation of the Republic of Indonesia Number 103 Year 2015 concerning Housing Ownership or Residence by Foreigners Domiciled in Indonesia, it is stated that in order to support the increasing development of cooperation of Indonesia with friendly countries, and

${ }^{18}$ Munir Fuady, Konsep Hukum Perdata (Rajawali 2014).[181]. 
the growing number of foreigners working and doing business in Indonesia, resulting in increased demand for houses and residencies for foreigners, so a policy that provides certain legal framework and eases administration service and permit to obtain a right on the land for a residential or dwelling house for foreigners is needed. The ease which was decided is the still maintaining the principles of protection among others principles of nationality - that only Indonesian citizens may have the ownership right, whereas foreigners may only be granted the right to land in the form of Right to Use and Lease Rights. In connection with this, there is a need for restrictions on residence or dwelling houses that will be given to the foreigners.

Article 1 of Government Regulation of the Republic of Indonesia Number 103 of 2015 concerning Housing Ownership or Occupancy by Foreigners Domiciled in Indonesia determines that Foreigners based in Indonesia, hereinafter called the foreigners, is a person who is not an Indonesian citizen, who benefits, does business, works, or invests in Indonesia. In Article 2, it is determined as follows:

(1) Foreigners can use a house for residence or dwelling with the Right to Use.

(2) Foreigners who may use a house mentioned in paragraph (1) is a holder of a residence permit in Indonesia in accordance with the provisions of laws and regulations.

(3) In a case of death of foreigner, the residential or dwelling house mentioned in paragraph (2) may be inherited.

(4) In case the heir referred to in paragraph (3) is a foreigner, the foreign heir must have residence permit in Indonesia in accordance with the provisions of laws and regulations.

Under the provisions of Article 2 Government Regulation of the Republic of Indonesia Number 103 of 2015 concerning Housing Ownership or Occupancy by Foreigners Domiciled in Indonesia, expatriates who have a legal residence permit in Indonesia in Indonesia can own a house for a residence or residence with Right to Use. The house or residence can also be inherited. If the heir is a Foreigner, the heir must also have a residence permit in Indonesia in accordance with statutory provisions.

Residence or dwelling that may be owned by expatriates is a single house and a single unit apartment. The single house on land (Right of Use; or Right of Use on Right of Ownership) controlled based on the agreement of granting the Right 
of Use on Right of Ownership with the deed of Land Deed Making Officer. Flat or apartment units built on the land of the right of use. The foreigners are given the right of use for a new single house and the right of ownership on flat units over the right of use for new purchased apartment units. It is further stipulated in Article 4 paragraph (1) Minister of Agrarian and Spatial Planning / Head of the National Land Agency of the Republic of Indonesia Number 29 Year 2016 concerning Procedures for Granting, Releasing, or Transferring the Right to Ownership of Residential or Residential Houses by Foreigners Domiciled in Indonesia stated:

The house of residence or occupancy that may be owned by foreigners as referred to in Article 3 paragraph (1) constitutes:

1. Single house, above ground:

1. The Right to Use;

2. The Right to Use for Ownership Right under the agreement for the granting of the Right to Use on Ownership Right with the deed of the Land Deed Maker Officer; or

3. The Right to Use that comes from the changes in the Right to Use or Building Use Right.

2. The apartment Unit:

1. built on the land of the right to use;

2. originating from the changes in the ownership rights of the apartment unit.

Government Regulation of the Republic of Indonesia Number 103 of 2015 concerning Housing Ownershipor Occupancy by Foreigners Domiciled in Indonesia which regulates housing or occupancy that can be owned by expatriates must be related to the provisions of the Minister of Agriculture and Spatial Regulation / Head of the National Land Agency of the Republic of Indonesia Number 29 of 2016 concerning Procedures for Granting, Releasing, or Transferring the Right to Residential or Residential Property by Foreigners Domiciled in Indonesia, which regulates the list of minimum prices, located houses or residents which can be owned by foreigners. 
44 Corina Ealen, dkk: The Agrarian Law Policy...

Article 5 of the Minister of Agrarian and Spatial Regulation / Head of the National Land Agency of the Republic of Indonesia Number 29 of 2016 concerning Procedures for Granting, Releasing, or Transferring the Right to Residential or Residential Property by Foreigners Domiciled in Indonesia gives restrictions on ownership of residence by expatriates. In the provisions of Article 5 mention as follows:

(1) Houses of residence or dwelling as referred to in Article 4 are given with a minimum price limit as stated in the Attachment which is an integral part of this Ministerial Regulation;

(2) In addition to the minimum price limit as referred to in paragraph (1), for residential houses, it is also limited with the following provisions:

a. 1 (one) parcel of land per person / family; and

b. the widest land area is 2,000 (two thousand) square meters

(3) Under certain circumstances which have a tremendous positive impact on the growth of the Indonesian economy, the provision of residential houses may be granted with an area of more than 2,000 (two thousand) square meters, with the Minister's permission;

(4) The restrictions referred to in paragraph (1) and paragraph (2) do not apply to the ownership of residential or residential houses by representatives of foreign countries and / or representatives of international bodies.

Residential houses owned by Foreigners on Ownership or Building Use Rights due to buying and selling, grants, exchanges, and auctions, as well as other means intended to transfer land rights, then the land of the Right to Ownership or Building Use Rights becomes the State's land that is directly given with the change to the Right of Use to the Foreigner concerned. Apartment unit which is built on Building Use Rights or Management Rights owned by Foreigners because of buying and selling, grants, exchanges, and auctions, as well as other means intended to transfer rights, the Right of Ownership of Flat Housing Unit is given with changes to Rights to Use the Unit for Flats to the Foreigners concerned.

The house of residence on the Right of Use originating from Ownership Rights is granted for a period of 30 (thirty) years. The Right to Use may be extended for a period of 20 (twenty) years. In the event that the term of the extension expires, the Right of Use can be renewed for a period of 30 (thirty) years. The house of residence on the Right of Use originating from the Building Use Right is granted 
with a period of time for the remaining period of validity of the Building Right concerned. The Right to Use can be extended for a period of 20 (twenty) years. In the term of the extension expires, the Right of Use can be renewed for a period of 30 (thirty) years.

The Right to Use for an apartment unit that is obtained for the first time from a Unit of Ownership Rights over a new Flats Unit, granted for a period of 30 (thirty) years, and may be extended for a period of 20 (twenty) years, and can be renewed for a period 30 (thirty) years. The Right to Use on the Unit of Flats which is derived from the Ownership of the Unit of the Flats is given with a period of time for the remaining period of validity of the Ownership of Unit concerned. The Right to Use for Unit Flats can be extended for a period of 20 (twenty) years, and can be renewed for a period of 30 (thirty) years.

Provisions regarding ownership of residence by foreigners also regulate the inheritance of the residence when the expatriate dies. If the foreigners die, the residence can be inherited. In the case that the heir is a Foreign Person, the heir must have a residence permit in Indonesia in accordance with the provisions of the legislation. Article 10 of the Republic of Indonesia Government Regulation No. 103 of 2015 concerning Housing Ownership or Occupancy by Foreigners Domiciled in Indonesia determines (1) When foreigner or heir who is a foreigner, who uses a house built on the grounds of the Right to Use or an agreement with the holders of land right is no longer domiciled in Indonesia, within a period of 1 (one) year shall release or transfer the right on the house and land to other party which meets requirements. (2) If within the period as referred to paragraph (1) the right on the house and land have not been released or transferred to other party which meets requirements:

1. house is state auctioned in case of being built on the grounds of the Right to Use on State land;

2. the house becomes property of the holder of land rights, in case the house was built on the grounds under an agreement as referred to in Article 4 number $1 \mathrm{~b}$. 
46 Corina Ealen, dkk: The Agrarian Law Policy...

The auction results as referred to in paragraph (2) letter a shall be a right of the former right holder.

\section{Conclusion}

The state has the responsibility in regulating land tenure. On the one hand, Indonesia has an obligation to protect land tenure for the national interest, but on the other hand has a legal obligation to provide space for expatriates to reside in Indonesia. According to the principle of the state responsibility, the state has an obligation to protect foreigners, both for themselves and for their property. Based on these principles, Indonesia provides a legal instrument that legitimizes the domination of residence by expatriates. In its development, the expatriates can control the residence with a lease agreement and the right of use over a single house and apartment units. A residential tenancy agreement is carried out between expatriates and Indonesian citizens as homeowners. Government policies provide the right of use in the ownership of residences in the form of single houses and apartment units for expatriates. The expatriate ownership of residence is limited by the price and area of land.

\section{Bibliography}

\section{Books}

Abdulkadir Muhammad, Hukum Perdata Indonesia (Citra Additya Bakti 2014).

Adolf H, Aspek-Aspek Negara Dalam Hukum Internasional (PT Raja Grafindo Persada 2002).

Jawahir Tontowi dan Pranoto Iskandar, Hukum Internasional Kontemporer (Refika Aditama 2006).

Munir Fuady, Konsep Hukum Perdata (Rajawali 2014).

Titik Triwulan Tutik, Hukum Perdata Dalam Sistem Hukum Nasional (Kencana Prenada Media Group 2011).

Urip Santoso, Hukum Agraria \& Hak-Hak Atas Tanah (Kencana Prenada Media Group 2008). 


\section{Journals}

Hartanto JA, 'Legal Aspects of Land Purchase/Sale Disputes in Indonesia' (2018) 48 Environmental Policy and Law.

Huang, Chun-Wei, Robert I. McDonald and KCS, 'The Importance of Land Governance for Biodiversity Conservation in an Era of Global Urban Expansion' (2018) 173 Landscape and Urban Planning.

Kristiansen, S. \& Sulistiawati L', 'Traditions, Land Rights, and Local Welfare Creation: Studies from Eastern Indonesia' (2016) 52 Bulletin of Indonesian Economic Studies.

McNulty, Y., \& Brewster C, 'Theorizing the Meaning (s) of "Expatriate": Establishing Boundary Conditions for Business Expatriates' (2017) 28 The International Journal of Human Resource Management.

Pangestu, S., \& Dharmastuti, C. F., 'What Characteristics of Board of Directors Affect Indonesian Bank Performance' (2018) 6 International Journal of Accounting and Economics Studies.

Prihadyanti, D., Sari, K., \& Hidayat D, 'Peran Ekspatriat Dalam Penguatan Kompetensi Inti Perusahaan' (2018) 17 Journal of Technology Management.

Randang IS, 'Tinjauan Yuridis Tentang Peranan Identitas Domisili Dalam Menentukan Kompetensi Relatif Pengadilan' (2016) 4 Lex Privatum.

Reki ND, 'Pembatasan Pemilikan Dan Penguasaan Hak Atas Tanah Dalam Perspektif Reforma Agraria' (2018) 1 Jurnal Hukum Magnum Opus.

Sudiro A, 'Measuring the Openness of Land Investment Policy Related to Housing or Residential Ownership by Foreigners in Indonesia' (2018) 21 European Research Studies Journal.

Sumanto L, 'Pembatasan Pemilikan Hak Atas Tanah Oleh Orang Asing Dan Badan Hukum Asing (Studi Perbandingan Indonesia-Turki)' (2016) 3 Jurnal Hukum PRIORIS. 
48 Corina Ealen, dkk: The Agrarian Law Policy...

--This page is intentionally left blank-- 